\title{
Streptococcus iniae infections in Red Sea cage-cultured and wild fishes
}

\author{
A. Colorni ${ }^{1, *}$, A. Diamant ${ }^{1}$, A. Eldar ${ }^{2}$, H. Kvitt ${ }^{1}$, A. Zlotkin ${ }^{3}$ \\ ${ }^{1}$ Israel Oceanographic and Limnological Research, National Center for Mariculture, PO Box 1212, Eilat 88112, Israel \\ ${ }^{2}$ Department of Poultry and Fish Diseases, The Kimron Veterinary Institute, PO Box 12, Bet Dagan 50250, Israel \\ ${ }^{3}$ Department of Clinical Microbiology, The Hebrew University of Jerusalem, Hadassah Medical School, PO Box 12272, \\ Jerusalem 91120, Israel
}

\begin{abstract}
Streptococcus iniae was isolated from 2 moribund wild Red Sea fishes, Pomadasys stridens (Pomadasyidae) and Synodus variegatus (Synodontidae), both collected in shallow waters along the Israeli coast of the Gulf of Eilat. The site is approximately $2 \mathrm{~km}$ from a mariculture cage farm in which streptococcal infections were diagnosed in previous years in the red drum Sciaenops ocellatus. This is the first report of $S$. iniae in Red Sea fishes. Biochemical and molecular similarities between the isolates from cultured fishes and those from the wild specimens suggest that a single strain is involved, and that 'amplification' and dispersal of this pathogen from captive to feral fishes have occurred. At the molecular level, the pathogen is different from the $S$. iniae isolates that have been afflicting the Israeli freshwater aquaculture in recent years. Although $S$. iniae prevalence in the wild fish populations of the area remains to be determined, the northernmost region of the Gulf of Eilat, virtually landlocked and with generally calm seas and weak currents, seems to be particularly vulnerable to the impact of diseases that develop in this mariculture system.
\end{abstract}

KEY WORDS: Fish disease $\cdot$ Mariculture $\cdot$ Red drum $\cdot$ Sciaenops ocellatus $\cdot$ Sea bass $\cdot$ Dicentrarchus labrax $\cdot$ Tilapia $\cdot$ Oreochromis mossambicus $\cdot 16 \mathrm{~S}$ rRNA $\cdot$ PCR

\section{INTRODUCTION}

A large variety of Gram-positive cocci in chains has been isolated from aquatic animals, including frogs (Liu 1982), crabs (Pappalardo \& Boemare 1982), prawn and shrimp (Brock 1983, Colorni unpubl. data), fish (see Austin \& Austin 1999 for an updated review) and mammals (see Lauckner 1985). In cultured fishes, streptococcal infections often develop into lethal septicaemic conditions. Fish in both freshwater and marine environments may be affected, and farms in many parts of the world have consequently suffered serious economic losses (Kusuda \& Komatsu 1978, Kitao 1993, Austin \& Austin 1999). The taxonomic position of many aquatic isolates is still controversial (Austin \& Austin 1999) but, as a whole, Streptococcus spp. have been

*E-mail: colorni@attglobal.net recently listed among the emerging problems in aquaculture (Austin 1999).

In the Gulf of Eilat (Israel, Red Sea), 2 major commercial cage farms are presently operating, producing over 2000 tons of fish a year, mainly of gilt-head sea bream Sparus aurata and, to a lesser extent, European sea bass Dicentrarchus labrax and red drum Sciaenops ocellatus (H. Gordin, Israel Ministry of Agriculture, 2001, pers. comm.). None of these species is native to the Red Sea. Many species of wild fishes are attracted by the cage structures, where they find shelter and an abundant supply of food (Diamant et al. 2000). They often gain access into the cages through the mesh, while farmed species manage to escape into the surrounding ecosystem. In particular, S. aurata of various sizes can be commonly sighted in shallow water along the northern beach of Eilat and Aqaba, where they are often caught by handlines, traps and gillnets (Khalaf \& Disi 1997, A. Colorni pers. obs.). The mingling of fish 
populations increases the opportunity for disease transmission in both directions, since translocated species may not only be extremely sensitive to a local pathogen but may themselves carry exotic diseases that can spread to indigenous wild populations (Paperna 1998).

In the Eilat region, streptococcosis has recurred repeatedly since it was first diagnosed in 1996 in the red drum (see Table 1). During the summer of 2000, persistent mortalities of wild fishes in the shallow waters of Eilat's northern coast were investigated. Gram-positive cocci in chains were isolated from 2 moribund wild specimens and compared with streptococcal isolates from fishes cultured in this region in previous years.

\section{MATERIALS AND METHODS}

Fishes. The infection chronology, sources of isolation and list of fish hosts are summarized in Table 1. The first case was diagnosed in 1995 in a stock of European sea bass Dicentrarchus labrax submitted to our laboratory for examination from a fish farm in Ashdod, on the Mediterranean coast of Israel. All subsequent cases refer to fish grown in the Eilat area (Red Sea). Water in this region is subjected to limited seasonal fluctuations of temperature $\left(23 \pm 1.5^{\circ} \mathrm{C}\right)$ and salinity $(40 \pm 1 \%)$. Red drum Sciaenops ocellatus were examined during mortality outbreaks in the cages. The tilapia Oreochromis mossambicus, adapted to seawater, were maintained at Israel Oceanographic and Limnological Research National Center for Mariculture in the facilities of the Reproduction Department for experimental purposes. The lined piggy Pomadasys stridens (Pomadasyidae) and the lizard fish Synodus variegatus (Synodontidae) were wild fishes, collected moribund in shallow waters on the North Beach of Eilat. In addition to bacteriological tests, routine parasitological and histopathological examinations were performed. In the fall of 2000, 2 dif-

Table 1. Streptococcus iniae. Dates, hosts and locations of isolations

\begin{tabular}{|lll|}
\hline Date & Host & Origin \\
\hline Oct 95 & Dicentrarchus labrax & Ashdod, Med Sea (cages) \\
Nov 96 & Sciaenops ocellatus & Eilat, Red Sea (cages) \\
Oct 98 & Oreochromis mossambicus & Eilat, Red Sea (tank) \\
Nov 98 & Sciaenops ocellatus & Eilat, Red Sea (cages) \\
Oct 99 & Sciaenops ocellatus & Eilat, Red Sea (cages) \\
Feb 00 & Sciaenops ocellatus & Eilat, Red Sea (cages) \\
Mar 00 & Sciaenops ocellatus & Eilat, Red Sea (cages) \\
Jun 00 & Pomadasys stridens & Eilat, Red Sea (wild) \\
Jul 00 & Synodus variegatus & Eilat, Red Sea (wild) \\
Oct 00 & Dicentrarchus labrax & Eilat, Red Sea (pond) \\
Nov 00 & Dicentrarchus labrax & Eilat, Red Sea (cages) \\
\hline
\end{tabular}

ferent stocks of European sea bass D. labrax reared in a $100 \mathrm{~m}^{3}$ PVC-lined pond and in sea cages were found to be similarly infected.

Bacterial isolates. Bacterial isolations were carried out from blood or spleen of diseased fishes. Tryptic Soy Agar (TSA; Difco) prepared with 25\% aged seawater, either alone or supplemented with $5 \%$ outdated human blood-bank blood, and an incubation temperature of $24 \pm 1^{\circ} \mathrm{C}$ were used for culture. All the isolates were preserved in $8 \%$ glycerol at $-70^{\circ} \mathrm{C}$. After thawing, subcultures were made on TSA for the identification tests. Presumptive identification of the isolates was made using 2 commercial kits, API 20 Strep and API $50 \mathrm{CH}$ (BioMérieux). Manufacturers' instructions were followed except for the incubation temperature, which was maintained at $24 \pm 1^{\circ} \mathrm{C}$ instead of the recommended $36 \pm 1^{\circ} \mathrm{C}$, and the intermediate readings which were not taken before $18 \mathrm{~h}$. Final results were read $72 \mathrm{~h}$ after inoculation and compared with the biochemical profiles described by Eldar et al. (1994).

16S rDNA, RAPD and AFLP analyses. Definitive identification of the isolates was further sought by polymerase chain reaction (PCR) of a $300 \mathrm{bp}$ long sequence in the 16S rDNA using primers specific for Streptococcus iniae, as described by Zlotkin et al. (1998). PCR products from template DNA of needletouched bacterial colonies were resolved in $2 \%$ agarose gel and stained with ethidium bromide. Isolates of Dicentrarchus labrax (October 1995), Sciaenops ocellatus (November 1996) and Synodus variegatus (July 2000) were selected for sequencing. For these 3 isolates, Primers U-1 and U-1500 (Escherichia coli 16S rDNA sequence, GenBank Accession No. J01859, Positions 7 to 27 and 1516 to 1540 respectively) were used for $16 \mathrm{~S}$ rDNA amplification and sequencing. Automated DNA sequencing was done at the Laboratory for DNA Analysis, Institute of Life Sciences, Hebrew University of Jerusalem, by the method of dye terminator cycle-sequencing using fluorescent-labeled dye terminators (PE Biosystems), and an ABI 377 automated DNA sequencer (PE Biosystems). Resulting nucleotide sequences were compared with the database deposited in the GenBank.

To detect possible genetic heterogeneity among the 11 isolates, random amplified polymorphic DNA (RAPD; Welsh \& McClelland 1990, Bachrach et al. 2001) and amplified fragment-length polymorphism (AFLP; Zabeau \& Vos 1993, Vos et al. 1995) analyses were also carried out. Streptococcus iniae ATCC (American Type Culture Collection, Manassas, Virginia, USA) Type Strain \#29178 ${ }^{\mathrm{T}}$ was used as reference.

Five mg of pure fresh bacterial cultures were ground gently on ice with $300 \mu$ l of grinding buffer (100 mM Tris-HCl pH 9, 100 mM EDTA, 1\% SDS). 
The homogenate was incubated at $70^{\circ} \mathrm{C}$ for $30 \mathrm{~min}$; $42 \mu \mathrm{l}$ of $8 \mathrm{M}$ potassium acetate was then added and gently mixed for $1 \mathrm{~min}$. The sample was placed on ice for $30 \mathrm{~min}$, then centrifuged at $4^{\circ} \mathrm{C}, 12000 \mathrm{rpm}$ for $15 \mathrm{~min}$. The supernatant was immediately transferred to a fresh tube and again centrifuged at $4^{\circ} \mathrm{C}, 12000 \mathrm{rpm}$ $(15300 \times g)$ for $5 \mathrm{~min}$. The centrifugation step was repeated until no traces of pellet were visible. DNA was precipitated with 1 volume of isopropanol for $15 \mathrm{~min}$ at room temperature. Pelleted DNA was washed in $70 \%$

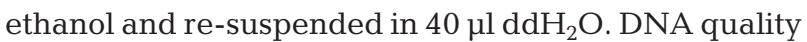
was assessed by electrophoresis in $0.7 \%$ agarose gel and ethidium bromide staining. DNA quantity and purity (260:280 ratio) were also estimated in a RNA:DNA calculator (Gene Quant pro, Amersham).

For RAPD, primer p14 (5'-GATCAAGTCC) (Gardiner et al. 1995, Bachrach et al. 2001) was selected. A typical $50 \mu \mathrm{l}$ PCR reaction mixture contained $50 \mathrm{mM}$ $\mathrm{KCl}, 10 \mathrm{mM}$ Tris-HCl (pH 8.8), $1.5 \mathrm{mM} \mathrm{MgCl}_{2}, 0.1 \%$ (vol/vol) Triton X-100, $200 \mu \mathrm{M}$ deoxyribonucleotides, 50 pmol primer, 2 U Taq DNA polymerase (Promega), and 20 to $50 \mathrm{ng}$ of DNA. The amplification cycles were as described by Neeman et al. (1998) for Streptococcus strains. Amplified DNA fragments were separated by electrophoresis in $1.5 \%$ agarose gel and visualized by ethidium bromide staining. The gels were photographed and the RAPD band patterns of the isolates were compared.

For the AFLP reactions, restriction enzyme digests, adapter annealing, and amplification procedures were performed as described by Vos et al. (1995), with the following modifications: $500 \mathrm{ng}$ of genomic DNA were digested with $20 \mathrm{U}$ of ECoRI and $5 \mathrm{U}$ of MseI restriction endonuclease for $3 \mathrm{~h}$ at $37^{\circ} \mathrm{C}$. Preamplification was performed with the AFLP adapters ECoRI-adapter: 5'-CTCGTAGACTGCGTACC (E1) and MseI-adapter: 5'GACGATGAGTCCTGAG (M1).

The cycling parameters were: denaturation step ( 2 min at $94^{\circ} \mathrm{C}$ ) followed by 19 cycles of $30 \mathrm{~s}$ denaturation $\left(94^{\circ} \mathrm{C}\right), 30 \mathrm{~s}$ annealing $\left(50^{\circ} \mathrm{C}\right)$ and $1 \mathrm{~min}$ extension $\left(72^{\circ} \mathrm{C}\right)$. AFLP reactions employed 2 oligonucleotide primers, M1 corresponding to the MseI ends and a radioactively labeled EcoRI primer (5-GACTGCGTACCAATTN-3) corresponding to the ECoRI ends. The ECoRI primers had 1 selective nucleotide extension $(\mathrm{N}=\mathrm{G}, \mathrm{A}, \mathrm{T}$ or $\mathrm{C}$ ). In each reaction, 1 selective EcoRI primer was employed; 4 primer combinations were used to detect AFLP variation between isolates. The cycling parameters were as described for the preamplification, with the annealing time extended to $1 \mathrm{~min}$. Of each sample, $4 \mu \mathrm{l}$ were loaded into $6 \%$ denaturing polyacrylamide gels (8 $\mathrm{M}$ urea) and electrophoresed for $2 \mathrm{~h}$ at $2000 \mathrm{~W}$, after which the gels were transferred onto chromatography paper, dried and exposed overnight (14 to $18 \mathrm{~h}$ ) to FUJI Medical X-
Ray Film, at room temperature. The total number of amplified bands was scored.

\section{RESULTS}

Clinical signs varied with the species affected. Dicentrarchus labrax and Sciaenops ocellatus were emaciated and presented skin lesions, severe bilateral exophthalmia, corneal opacity or complete eye degeneration. Gill capillaries were often obstructed by gas bubbles and presented haemorrhagic and necrotic areas ('gill rot'). Haemorrhage was also conspicuous in the abdominal cavity. Histological sections showed that the organs most commonly affected by massive coccal invasion were the heart and spleen. Although moribund, the wild fishes displayed no marked gross signs of the disease. A ciliate, Trichodina sp., infected the gills of both Pomadasys stridens and Synodus variegatus, and a flagellate, Cryptobia sp., infected the gills of $P$. stridens.

Bacterial cultures produced punctiform, translucent to slightly opaque colonies that became round, convex, whitish, $1.50 \pm 0.25 \mathrm{~mm}$ in diameter and $\alpha$-hemolytic after $72 \mathrm{~h}$. With the exception of 1 case (red drum, October 1999, in which Vibrio carchariae was also isolated from the fish blood), pure streptococcal cultures were obtained. Their biochemical profile is summarized in Table 2.

The 300 bp PCR-amplified product was detected in all the isolates (data not shown). Sequences of all 3 isolates tested were identical and showed $100 \%$ similarity to the ATCC $29178^{\mathrm{T}}$ Streptococcus iniae type strain (GenBank Accession No. AF335572). The RAPD patterns consisted of 5 distinct DNA fragments, approximately 2500, 2000, 1400, 1100 and 850 bp long (Fig. 1). The total number of AFLP bands per primer set ranged from 70 to 134 . Summing the bands of the 4 primer combinations revealed 461 distinct bands. All 11 isolates and the ATCC reference strain shared identical RAPD and AFLP patterns.

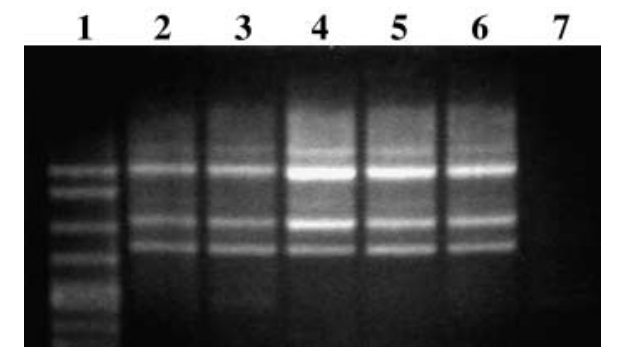

Fig. 1. RAPD patterns of representative isolates obtained with Primer p14. Lane 1: AmpliSize ${ }^{\mathrm{TM}}$ molecular weight marker; Lanes 2-6: ATCC Strain \#29178 ${ }^{\mathrm{T}}$ and Isolates 1, 11, 12 and 13, respectively; Lane 7: no DNA 
Table 2. Streptococcus iniae. Biochemical profile isolated in Mediterranean Sea cultured, Red Sea cultured and Red Sea wild fishes (+: positive reaction; -: no reaction; v: variable)

\begin{tabular}{|c|c|c|c|c|c|}
\hline Gram & + & $\alpha$-methyl-D-glucoside & - & L-arabitol & - \\
\hline Catalase & - & $\mathrm{N}$-acetyl glucosamine & + & Gluconate & - \\
\hline \multirow[t]{2}{*}{ Hemolysis } & $\alpha$ & Amygdalin & + & 2-keto-gluconate & - \\
\hline & & Arbutin & + & 5-keto-gluconate & - \\
\hline API $50 \mathrm{CH}$ & & Esculin & + & API 20 Strep & \\
\hline Glycerol & - & Salicin & + & VP (acetoin prod.) & - \\
\hline Erythritol & - & Cellobiose & + & Hippurate hydrol. & - \\
\hline D-arabinose & - & Maltose & + & Esculin ( $\beta$-glucosidase) & + \\
\hline L-arabinose & - & Lactose & - & PYRA (pyrrolidonyl arylamidase) & + \\
\hline Ribose & + & Melibiose & - & $\alpha$-GAL ( $\alpha$-galactosidase) & - \\
\hline D-xylose & - & Sucrose & + & $\beta$-GUR ( $\beta$-glucuronidase) & + \\
\hline L-xylose & - & Trehalose & + & $\beta$-GAL ( $\beta$-galactosidase) & - \\
\hline Adonitol & - & Inulin & - & PAL (alkaline phosphatase) & + \\
\hline$\beta$-methyl-D-xyloside & - & Melezitose & + & LAP (L-leucine arylamidase) & + \\
\hline Galactose & + & D-raffinose & - & ADH (arginine dihydrolase) & $\mathrm{v}$ \\
\hline D-glucose & + & Starch & + & RIB (ribose acidif.) & + \\
\hline D-fructose & + & Glycogen & + & ARA (L-arabinose acidif.) & - \\
\hline D-mannose & + & Xylitol & - & MAN (mannitol acidif.) & + \\
\hline L-sorbose & - & $\beta$-gentiobiose & + & SOR (sorbitol acidif.) & - \\
\hline Rhamnose & - & D-turanose & - & LAC (lactose acidif.) & - \\
\hline Dulcitol & - & D-lyxose & - & TRE (trehalose acidif.) & + \\
\hline Inositol & - & D-tagatose & - & INU (inulin acidif.) & - \\
\hline Mannitol & + & D-fucose & - & RAF (raffinose acidif.) & - \\
\hline Sorbitol & - & L-fucose & - & AMD (starch acidif.) & + \\
\hline$\alpha$-methyl-D-mannoside & _ & D-arabitol & _ & GLYG (qlycoqen acidif.) & + \\
\hline
\end{tabular}

\section{DISCUSSION}

The biochemical profile of the streptococcus isolated in this study is consistent with its identification as Streptococcus iniae and appears to be quite similar to that drawn by Eldar et al. $(1994,1995)$ for isolates from trout and tilapine fishes. The only differences consist in the reaction to arginine dihydrolase (produced only by the first 3 isolates) and in a late fermentation of galactose and amygdalin in all isolates. At the molecular level, the PCR amplification with primers specific for $S$. iniae's 16 rDNA sequence confirmed the identification of the species.

Comparison of the 16S rRNA sequence with that from Streptococcus iniae isolates from Israeli trout (GenBank Accession No. AF335573) revealed 6 nucleotide differences (from a total of approximately 1500), which corresponds to $99.6 \%$ homology. Therefore, despite phenotypical, biochemical and pathogenetic similarities, this freshwater isolate and our more recent Israeli marine isolates appear to be different intraspecific strains. Using restriction fragment length polymorphism (RFLP) of whole rRNA S. iniae genes (ribotyping), Eldar et al. (1997) showed that Israeli isolates from tilapia and (with 1 exception) trout could be differentiated from US $S$. iniae isolates from tilapia, and ruled out the possibility of an epidemiological link between $S$. iniae freshwater isolates in the 2 countries. These authors also showed that the $S$. iniae ATCC $29178^{\mathrm{T}}$ type strain (orig- inally isolated from skin lesions of an Amazon River freshwater dolphin, Inia geoffrensis, held in captivity in San Francisco, California; Pier \& Madin 1976) belongs to a ribotype different from those of the piscine isolates.

In our study, a $100 \%$ similarity was shown in the sequences of the 16S rRNA gene between the Mediterranean isolate, the Red Sea isolates and the Streptococcus iniae ATCC $29178^{\mathrm{T}}$ type strain. Neither the AFLP nor the RAPD method revealed any strain variation, despite the fact that both methods demonstrate high discriminative properties, the former differentiating among strictly related bacterial strains (Janssen et al. 1996, Blears et al. 1998), and the latter among Group-A streptococci (Gardiner et al. 1995) and even S. iniae serotypes (Bachrach et al. 2001).

Several comprehensive bacteriological studies on fishes farmed in the Red Sea have been carried out (e.g. Colorni et al. 1981, Colorni 1992), but this is the first report of Streptococcus iniae in cultured or wild fishes in the area. While the possibility that these isolates belong to a strain endemic to the Red Sea region cannot be ruled out, the lack of historical documentation of the disease in the area prior to 1996, and the initial appearance of streptococcosis in the Israeli marine aquaculture on both Mediterranean and Red Sea coasts that roughly coincided with the first imports of red drum fingerlings from Texas for culture at both sites (see Colorni \& Diamant 1995, Eldar et al. 1999), suggest that the Israeli marine isolates have their ori- 
gin in the species introduced for aquaculture in recent years. Biochemical, molecular and epidemiological similarities between the $S$. iniae isolate from the Mediterranean coast of Israel and the Red Sea isolates further strengthen this hypothesis.

The 2 wild specimens of fishes examined in the present study were collected in shallow waters at a distance of approximately $2 \mathrm{~km}$ from the cage farms, suggesting that an 'amplification' and dispersal of Streptococcus iniae from captive to feral fish have occurred. A similar pattern has been recently observed in the same region with regard to another fish pathogen associated with cage culture, Mycobacterium marinum (Diamant et al. 2000, Diamant 2001). However, since $S$. iniae causes an acute malady with less conspicuous pathology, its prevalence in the wild fish populations of the area is difficult to assess. In Japan, streptococci have been isolated from wild fishes (sardines, anchovies, round herring, chub mackerel, black scraper), seawater and bottom mud from the vicinity of sea cages (Minami 1979, Kusuda \& Kawai 1982), and a prolonged survival was observed in the environment (Kusuda \& Kawai 1982). In the US, mortalities of wild fishes infected with Streptococcus spp. were recorded in Alabama, the northwest Florida coast of the Gulf of Mexico (Plumb et al. 1974, Cook \& Lofton 1975) and in the Chesapeake Bay and its tributaries (Baya et al. 1990). A massive kill of reef fishes in the south-east Caribbean Sea was associated with $S$. iniae (Ferguson et al. 2000). In Israel, $S$. iniae has been isolated on the Mediterranean coast of Israel from diseased wild rabbitfish Siganus rivulatus collected near a site where gilt-head sea bream Sparus aurata and sea bass Dicentrarchus labrax cultured in floating net cages exhibited a similar infection (Zlotkin et al. 1998).

Topographic conditions make certain types of site or specific areas particularly sensitive or vulnerable to cage aquaculture (Beveridge 1996). The ecological implications of this farming method are particularly important in the narrow northernmost region of the Gulf of Eilat, where the sea is generally calm and currents are weak, as patterns of occurrence, prevalence and pathogenicity of some disease agents have greatly changed in recent years (Diamant \& Colorni 1995, Diamant et al. 2000).

Acknowledgements. The technical assistance of Yariv Shtupler is gratefully acknowledged. We are indebted to H. Gordin, Israel Ministry of Agriculture, Dr. A. Tandler, Director of $\mathrm{NCM}$, and an anonymous referee for their critical review of the manuscript. Thanks are also due to Dr. A. Genin of the Interuniversity Institute for Marine Sciences of Eilat, and Dr. T. Berman, Israel National Museum of Science, Haifa, for the hydrokinetic data of the currents in the Gulf of Eilat. This research was carried out at the Green-Keiser Fish Health Center, IOLR-NCM, Eilat, with the support of the Yad Hanadiv Fund and the Israel Ministry of National Infrastructures.

\section{LITERATURE CITED}

Austin B (1999) Emerging bacterial fish pathogens. Bull Eur Assoc Fish Pathol 19:231-234

Austin B, Austin DA (1999) Bacterial fish pathogens: disease of farmed and wild fish, 3rd edn. Springer-Praxis, Chichester

Bachrach G, Zlotkin A, Hurvitz A, Evans DL, Eldar A (2001) Recovery of Streptococcus iniae from diseased fish previously vaccinated with a Streptococcus vaccine. Appl Environ Microbiol 67:3756-3758

Baya AM, Lupiani B, Hetrick FM, Roberson BS, Lukacovic R, May E, Poukish C (1990) Association of Streptococcus sp. with fish mortalities in the Chesapeake Bay and its tributaries. J Fish Dis 13:251-253

Beveridge M (1996) Cage aquaculture, 2nd edn. Fishing news books. Blackwell, Oxford

Blears MJ, De Grandis SA, Lee H, Trevors JT (1998) Amplified fragment length polymorphism (AFLP): a review of the procedure and its applications. J Ind Microbiol Biotechnol 21:99-114

Brock JA (1983) Diseases (infectious and noninfectious), metazoan parasites, predators, and public health considerations in Macrobrachium culture and fisheries. In: McVey JP (ed) CRC handbook of mariculture, Vol 1. Crustacean aquaculture. CRC Press, Boca Raton, FL, p 329-370

Colorni A (1992) A systemic mycobacteriosis in the European sea bass Dicentrarchus labrax cultured in Eilat (Red Sea). Isr J Aquacult Bamidgeh 44:75-81

Colorni A, Diamant A (1995) Splenic and cardiac lymphocystis in the red drum, Sciaenops ocellatus (L.). J Fish Dis 18: 467-471

Colorni A, Paperna I, Gordin H (1981) Bacterial infections in gilt-head sea bream Sparus aurata cultured at Elat. Aquaculture 23:257-267

Cook DW, Lofton SR (1975) Pathogenicity studies with a Streptococcus sp. isolated from fishes in an AlabamaFlorida fish kill. Trans Am Fish Soc 2:286-288

Diamant A (2001) Cross-infections between marine cagecultured stocks and wild fish in the northern Red Sea: is the environment at risk? In: CJ Rodgers (ed) Proceedings of the OIE International Conference on Risk Analysis in Aquatic Animal Health, Paris, France, 8-10 February 2000. OIE, Paris, p 202-208

Diamant A, Colorni A (1995) Net-pen mariculture: a potential source of dispersal of Mycobacterium to native fish. European Association of Fish Pathologists, Seventh International Conference, Palma de Mallorca, September 1995. EAFP, Palma de Mallorca, p 66 (Abstract)

Diamant A, Banet A, Ucko M, Colorni A, Knibb W, Kvitt H (2000) Mycobacteriosis in wild rabbitfish Siganus rivulatus associated with cage farming in the Gulf of Eilat, Red Sea. Dis Aquat Org 39:211-219

Eldar A, Bejerano Y, Bercovier H (1994) Streptococcus shiloi and Streptococcus difficile: two new streptococcal species causing a meningoencephalitis in fish. Curr Microbiol 28: 139-143

Eldar A, Frelier PF, Assenta L, Varner PW, Lawhon S, Bercovier H (1995) Streptococcus shiloi, the name for an agent causing septicemic infection in fish, is a junior synonym of Streptococcus iniae. Int J Syst Bacteriol 45:840-842

Eldar A, Frelier PF, Asanta L, Varner PW, Lawhon S, Bercovier H (1997) DNA restriction length polymorphysm of rRNA genes (rybotyping) allows distinction between Israeli and US $S$. iniae trout and tilapia isolates. FEMS Microbiol Lett 151:155-162

Eldar A, Perl S, Frelier PF, Bercovier H (1999) Red drum Sci- 
aenops ocellatus mortalities associated with Streptococcus iniae infection. Dis Aquat Org 36:121-127

Ferguson HW, St John VS, Roach CJ, Willoughby S, Parker C, Ryan R (2000) Caribbean reef fish mortality associated with Streptococcus iniae. Vet Record 147:662-664

Gardiner D, Hartas J, Currie B, Mathews JD, Kemp DJ, Sriprakash KS (1995) Vir-typing: a long-PCR typing method for group A streptococci. PCR Methods Applic 4:288-293

Janssen P, Coopman R, Huys G, Swings J, Bleeker M, Vos P, Zabeau M, Kersters K (1996) Evaluation of the DNA fingerprinting method AFLP as a new tool in bacterial taxonomy. Microbiology (NY) 142:1881-1893

Khalaf MA, Disi AM (1997) Fishes of the Gulf of Aqaba. The Marine Science Station, Aqaba, National Press, Amman, Jordan

Kitao T (1993) Streptococcal Infections. In: Inglis V, Roberts RJ, Bromage NR (eds) Bacterial diseases of fish. Blackwell, Oxford, p 196-210

Kusuda R, Kawai K (1982) Characteristics of Streptococcus sp. pathogenic to yellowtail. Fish Pathol 17:11-16 (in Japanese with English abstract)

Kusuda R, Komatsu I (1978) A comparative study of fish pathogenic Streptococcus isolated from saltwater and freshwater fishes. Nippon Suisan Gakkaishi 44:1073-1078

Lauckner G (1985) Diseases of Mammalia: Pinnipedia. Agents: Bacteria. In: Kinne O (ed) Diseases of marine animals, Vol 4. Part 2. Biologische Anstalt Helgoland, Hamburg, p 695-707

Liu CI (1982) Pathology of the major diseases of bullfrogs (Rana catesbelana) in Taiwan. In: Proceedings of ROCJapan Cooperative Science Seminar on Fish Diseases. Tungkang Marine Laboratory, Tungkang, p 79-87

Minami T (1979) Streptococcus sp., pathogenic to cultured

Editorial responsibility: David Bruno, Aberdeen, Scotland, UK yellowtail, isolated from fishes for diets. Fish Pathol (Gyobyo Kenkyu) 14:15-19

Neeman R, Keller N, Barzilai A, Korenman Z, Sela S (1998) Prevalence of internalisation-associated gene, prtF1, among persisting group-A streptococcus strains isolated from asymptomatic carriers. Lancet 352:1974-1977

Paperna I (1998) Mariculture versus environment: risks and impacts. Biol Mar Mediterr 5:381-389

Pappalardo R, Boemare N (1982) An intracellular Streptococcus, causative agent of a slowly developing disease in the Mediterranean crab, Carcinus mediterraneus. Aquaculture 28:283-292

Pier GB, Madin SH (1976) Streptococcus iniae sp. nov., a beta hemolytic streptococcus isolated from an Amazon freshwater dolphin, Inia geoffrensis. Int J Syst Bacteriol 26: $545-553$

Plumb JA, Schachte JH, Gaines JL, Peltier W, Carrol B (1974) Streptococcus sp. from marine fishes along the Alabama and northwest Florida coast of the Gulf of Mexico. Trans Am Fish Soc 103:358-361

Vos P, Hogers R, Bleeker M, Reijans M and 7 others (1995) AFLP: a new concept for DNA fingerprinting. Nucleic Acids Res 21:4407-4414

Welsh J, McClelland M (1990) Fingerprinting genomes using PCR with arbitrary primers. Nucleic Acids Res 18: 7213-7218

Zabeau M, Vos P (1993) Selective restriction fragment amplification: a general method for DNA fingerprinting. Publication 0534858 A1, European Patent Office, Bulletin 93/13, Munich

Zlotkin A, Hershko H, Eldar A (1998) Possible transmission of Streptococcus iniae from wild fish to cultured marine fish. Appl Environ Microbiol 64:4065-4067

Submitted: August 6, 2001; Accepted: November 2, 2001 Proofs received from author(s): May 15, 2002 